\section{Scientific Societies Fostering Inclusive Scientific Environments through Travel Awards: Current Practices and Recommendations}

\author{
Verónica A. Segarra, ${ }^{1,2 *}$ Leticia R. Vega, ${ }^{2,3}$ Clara Primus, ${ }^{1}$ Candice Etson, ${ }^{4,5}$ \\ Ashley N. Guillory, ${ }^{6,7}$ Ashanti Edwards, ${ }^{2}$ Sonia C. Flores, ${ }^{8,9}$ Catherine Fry, ${ }^{7}$ \\ Susan L. Ingram, ${ }^{7,10}$ Mark Lawson, ${ }^{11,12}$ Richard McGee, ${ }^{13}$ Stephanie Paxson ${ }^{8}$ \\ Laura Phelan, ${ }^{5}$ Kirsta Suggs ${ }^{11}$ Elizabeth Vuong, ${ }^{5}$ Latanya Hammonds-Odie, ${ }^{2,14}$ \\ Michael J. Leibowitz, ${ }^{2,15}$ MariaElena Zavala, ${ }^{2,16} \mathrm{~J}$. Luis Lujan, ${ }^{17 *}$ and \\ Marina Ramirez-Alvarado, ${ }^{5,17 *}$ \\ ${ }^{1}$ Department of Biology, High Point University, High Point, NC 27268; ${ }^{2}$ American Society for Cell \\ Biology, Bethesda, MD 20852; ${ }^{3}$ Department of Biology, Barry University, Miami Shores, FL 33161; \\ ${ }^{4}$ Department of Physics, Wesleyan University, Middletown, CT 06459; ${ }^{5}$ Biophysical Society, \\ Rockville, MD 20852; ${ }^{6}$ Department of Physician Assistant Studies, University of Texas Medical \\ Branch at Galveston, Galveston, TX 77555; ${ }^{7}$ American Society for Pharmacology and Experimental \\ Therapeutics, Rockville, MD 20852; ${ }^{8}$ American Society for Biochemistry and Molecular Biology, \\ Rockville, MD 20852; ${ }^{\circ}$ Division of Pulmonary Sciences and Critical Care Medicine, University of \\ Colorado, Anschutz Medical Campus, CO 80045; ${ }^{10}$ Department of Neurological Surgery, Oregon \\ Health \& Science University, Portland, OR 97239; ${ }^{11}$ Endocrine Society, Washington, DC 20036; \\ ${ }^{12}$ Department Obstetrics, Gynecology, and Reproductive Sciences, University of California, \\ San Diego, San Diego, CA 92093; ${ }^{13}$ Northwestern University Feinberg School of Medicine, \\ Faculty Affairs, Chicago, IL 60611; ${ }^{14}$ School of Science and Technology, Georgia Gwinnett College, \\ Lawrenceville, GA 30043; ${ }^{15}$ Department of Medical Microbiology \& Immunology, University of \\ California, Davis, Davis, CA 95616; ${ }^{16}$ Department of Biology, California State University Northridge, \\ Northridge, CA 91330; ${ }^{17}$ Departments of Biochemistry, Molecular Biology and Immunology, \\ Mayo Clinic, Rochester, MN 55905
}

\begin{abstract}
Diversity-focused committees continue to play essential roles in the efforts of professional scientific societies to foster inclusion and facilitate the professional development of underrepresented minority (URM) young scientists in their respective scientific disciplines. Until recently, the efforts of these committees have remained independent and disconnected from one another. Funding from the National Science Foundation has allowed several of these committees to come together and form the Alliance to Catalyze Change for Equity in STEM Success, herein referred to as ACCESS. The overall goal of this meta-organization is to create a community in which diversity-focused committees can interact, synergize, share their collective experiences, and have a unified voice on behalf of URM trainees in science, technology, engineering, and mathematics disciplines. In this Essay, we compare and contrast the broad approaches that scientific societies in ACCESS use to implement and assess their travel award programs for URM trainees. We also report a set of recommendations, including both short- and long-term outcomes assessment in populations of interest and specialized programmatic activities coupled to travel award programs.
\end{abstract}

\section{INTRODUCTION}

Attending, networking, and presenting at scientific conferences sponsored by professional societies is an essential aspect of being a scientist. Conference participation helps scientists to disseminate the most recent advances in their disciplines and exchange ideas with peers to fuel transformational research. It also presents opportunities to
Adele Wolfson, Monitoring Editor

Submitted Dec 2, 2019; Revised Mar 26, 2020; Accepted Mar 27, 2020

CBE Life Sci Educ June 1, 2020 19:es3

DOI:10.1187/cbe.19-11-0262

*Address correspondence to: Verónica A. Segarra (vsegarra@highpoint.edu), J. Luis Lujan (Lujan. Luis@mayo.edu), or Marina Ramirez-Alvarado (RamirezAlvarado.Marina@mayo.edu).

() 2020 V. A. Segarra et al. CBE-Life Sciences Education @ 2020 The American Society for Cell Biology. This article is distributed by The American Society for Cell Biology under license from the author(s). It is available to the public under an Attribution-Noncommercial-Share Alike 3.0 Unported Creative Commons License (http://creativecommons.org/licenses/ by-nc-sa/3.0).

"ASCB $®$ " and "The American Society for Cell Biology ${ }^{\circledR}$ " are registered trademarks of The American Society for Cell Biology. 
establish a professional network and an identity within a field. Networking becomes even more important for scientists from underrepresented backgrounds, who are less frequently asked to speak about their work at conferences and more often feel isolated and marginalized (Casad et al., 2016; Ford et al., 2019).

For some, the cost of attending discipline-specific conferences is a relevant barrier to participation, as budget constraints have motivated many academic institutions to reduce their support for these vital activities. Professional scientific societies often offer travel awards to help their members defray the costs associated with attending their annual meetings (King, 2013; Le Duc and DeAcetis, 2011; Bolaños-Guzmán and Zarate, 2016; Segarra et al., 2017). Many societies have also used these travel award mechanisms to foster underrepresented minority (URM) representation and integration at their conferences (Le Duc and DeAcetis, 2011; Segarra et al., 2017), promoting the larger field the society represents to a diverse group of scientists and trainees. URM is a broad designation that refers to members of groups that are underrepresented in the scientific workforce (including Black/African-American, Hispanic/Latino, American Indian or Alaska Native, Native Hawaiian, and other Pacific Islander racial/ethnic groups), as described by the National Institutes of Health (NIH) and its Office of the Director for Scientific Workforce Diversity (NIH, n.d.). As scientific societies are increasingly recognized as potential support systems and developmental scaffolds for individual trainees across different career stages (Potvin et al., 2018; Segarra et al., 2019), diversity-focused committees have often been charged with designing and administering travel awards as part of their larger responsibility to foster inclusion and facilitate the professional development of URM members.

Some published metrics have provided insight into both the successes and shortcomings of travel award programming in promoting inclusive membership and professional development. While, in some cohorts, less than $10 \%$ of travel awardees maintained membership in the scientific societies that provided them with awards (Le Duc and DeAcetis, 2011), other accounts have identified prominent and well-represented (WR) and URM scientists/educators who first became involved with their preferred scientific societies through travel awards and sustained that engagement throughout their professional careers (Edwards, 2004; Cameron, 2013). More detailed insight into the factors underlying both the benefits and the limitations of existing travel award programming among science, technology, engineering, and mathematics (STEM) societies has been unavailable, in part because committees from different scientific societies have generally designed and implemented travel awards independently of one another. Funding from the National Science Foundation (NSF) has allowed several of these committees to come together and form the Alliance to Catalyze Change for Equity in STEM Success, herein referred to as ACCESS. ACCESS members include the American Society for Biochemistry and Molecular Biology (ASBMB), the American Society for Cell Biology (ASCB), the American Society for Pharmacology and Experimental Therapeutics (ASPET), the Biophysical Society (BPS), the Endocrine Society (ES), and the Scientific Careers Research and Development Group at Northwestern University. In general, intersociety coordination of efforts can bring about large-scale changes that are not possible from isolated interventions by individual organizations (Kania and Kramer, 2011, 2013). The ACCESS meta-organization is designed to function as a community of practice in which participants can share best practices and leverage their collective experiences to better address the needs and concerns of URM scientists in STEM disciplines.

This meta-organizational model places ACCESS in a position to assess outcomes and disseminate findings to the broader research community, including smaller societies working in similar ways to foster diverse and talented pools of trainees. In this Essay, we compare and contrast the diverse approaches to travel award implementation and assessment among the founding societies of ACCESS (Table 1), highlighting common features independently found to drive successful outcomes and synthesizing them to generate a set of recommendations for scientific society travel awards. To provide a context to these practices and recommendations, we share data from ACCESS member societies (High Point University Institutional Review Board approval no. 201910-858).

For example, Supplemental Tables S1 and S2 present demographic and career-stage information for the ASCB Minority Affairs Committee (MAC) travel awardees from 2005 to 2018. These data are similar and representative of all other ACCESS society members. Generally, in our annual meeting travel award programs, URM scientist participants are predominantly female students (early career) from Black and Hispanic backgrounds. While travel awards occasionally are a component of more comprehensive professional development programs (Ramirez and Tonidandel, 2009; Campbell et al., 2013; Jassar, 2015; Steiner and Leinwander, 2017; Mourad et al., 2018; Ahern-Dodson et al., 2020), the data shared in this Essay specifically represent the more typical stand-alone travel awards that are limited to providing funds to attend a society's annual meeting (Le Duc and DeAcetis, 2011; Segarra et al., 2017). We use the data presented to highlight the key factors known to motivate attendance to disciplinary conferences. Specific recommendations include the implementation of both short- and long-term assessment of outcomes in populations of interest and coupling of travel awards to specialized programmatic activities designed to support URM scientists at different career stages.

\section{TRAVEL AWARDS FROM A MOTIVATIONAL THEORY PERSPECTIVE}

Studies characterizing the motivations influencing conference attendance often identify cost, networking opportunities, professional development activities, and social aspects among the most important determinants (Mair and Thompson, 2009; Mair et al., 2018). We find that a natural overlap exists between these four motivational dimensions and the benefits ACCESS member societies aim to accomplish through their travel award programs. ACCESS member societies articulate the following set of shared goals for their travel award programs with respect to URM scientists:

1. Increase representation of URM scientists at annual meetings through sponsorship of costs associated with travel.

2. Provide opportunities for URM scientists to network with other society members.

3. Provide opportunities for URM scientists to access professional development opportunities (separate from networking).

4. Provide a community at the meeting to decrease sense of isolation for URM individuals. 
TABLE 1. Travel award programs from ACCESS member societies at-a-glance ${ }^{a}$

\begin{tabular}{|c|c|c|c|c|c|}
\hline $\begin{array}{l}\text { Society } \\
\text { (no. members) }\end{array}$ & $\begin{array}{l}\text { Current } \\
\text { URM travel award } \\
\text { budget per year } \\
\text { (number of staff) }\end{array}$ & $\begin{array}{c}\text { URM target } \\
\text { academic stages }\end{array}$ & $\begin{array}{c}\text { Application materials/ } \\
\text { process }\end{array}$ & Award amount & Programming \\
\hline $\begin{array}{l}\text { ASBMB } \\
\quad(14,007)\end{array}$ & $\begin{array}{l}\$ 16,000 \text { per year } \\
\quad \text { (3 staff members) }\end{array}$ & $\begin{array}{l}\text { Graduate students } \mathrm{PhD} \\
\text { or master's, } \\
\text { postdocs }\end{array}$ & $\begin{array}{l}\text { Abstract submission, } \\
\text { Membership, Curricu- } \\
\text { lum vitae, Letter of } \\
\text { support, Objectives } \\
\text { statement (research/ } \\
\text { career goal) }\end{array}$ & $\$ 1000$ & $\begin{array}{l}\text { General poster sessions, } \\
\text { networking sessions, } \\
\text { career development } \\
\text { events and sessions for } \\
\text { all grad/postdoc } \\
\text { awardees }\end{array}$ \\
\hline $\begin{array}{l}\text { ASCB } \\
\quad(7308)\end{array}$ & $\begin{array}{l}\$ 145,800 \text { per year } \\
\quad(3 \text { staff members })\end{array}$ & All stages & $\begin{array}{l}\text { Abstract submission } \\
\text { Membership } \\
\text { Curriculum vitae } \\
\text { Letter of support } \\
\text { Objectives statement }\end{array}$ & $\$ 1700$ & $\begin{array}{l}\text { Undergraduate orientation, } \\
\text { undergraduate poster } \\
\text { competition, general } \\
\text { poster sessions } \\
\text { presentation, networking } \\
\text { sessions, career } \\
\text { development sessions }\end{array}$ \\
\hline $\begin{array}{l}\text { ASPET } \\
\quad(4700)\end{array}$ & Varies per year & $\begin{array}{l}\text { Undergraduate, } \\
\text { postbaccalaureate, } \\
\text { graduate student } \\
\text { PhD or master's, } \\
\text { postdocs }\end{array}$ & $\begin{array}{l}\text { Abstract submission } \\
\text { Membership } \\
\text { Curriculum vitae } \\
\text { Letter of support } \\
\text { Objectives statement }\end{array}$ & $\begin{array}{l}\$ 800-\$ 1300 \\
\text { plus } \\
\text { registration }\end{array}$ & $\begin{array}{l}\text { Student/postdoctoral } \\
\text { colloquium and poster } \\
\text { presentation at the } \\
\text { exhibit hall }\end{array}$ \\
\hline $\begin{array}{l}\text { BPS } \\
\quad(7500)\end{array}$ & $\begin{array}{l}\$ 85,252 \text { per year } \\
\quad(2 \text { staff members })\end{array}$ & $\begin{array}{l}\text { Undergraduate, } \\
\text { graduate student, } \\
\text { scientists within } 10 \\
\text { years of professional } \\
\text { degree, scientists } \\
\text { 10+ years beyond } \\
\text { professional degree }\end{array}$ & $\begin{array}{l}\text { Abstract submission } \\
\text { Presenting author } \\
\text { Membership } \\
\text { Curriculum vitae } \\
\text { Letter of support* } \\
\text { Objectives statement } \\
\text { (research/career goal) }\end{array}$ & $\begin{array}{l}\$ 100-\$ 750 \\
\quad \text { (amount } \\
\text { based on } \\
\text { distance } \\
\text { from meeting } \\
\text { site) }\end{array}$ & Varies per year \\
\hline $\begin{array}{l}\text { ES } \\
(18,000+)\end{array}$ & $\$ 150,000$ per year & $\begin{array}{l}\text { Graduate student, } \\
\text { medical student, } \\
\text { postdoc and } \\
\text { clinical fellows, } \\
\text { junior faculty, early } \\
\text { career scientists/ } \\
\text { clinicians }\end{array}$ & $\begin{array}{l}\text { Abstract based, top-scored } \\
\text { abstracts selected based } \\
\text { on eligibility criteria }\end{array}$ & $\$ 400-\$ 1500$ & $\begin{array}{l}\text { Science education, } \\
\text { professional develop- } \\
\text { ment workshops, } \\
\text { networking opportuni- } \\
\text { ties, poster presentations }\end{array}$ \\
\hline
\end{tabular}

${ }^{a}$ This table summarizes the key components of the annual meeting URM travel award programs for ACCESS member societies. The information reflects program/society information at the end of 2019.

These goals are also reflected in self-reported ASCB travel award participant objectives (Table 2) and have guided the design of tools used to assess the degree to which those objectives are being met (Table 3). These similarities highlight the relevance of this body of literature to the motivations of our target groups. We discuss the motivational theory behind each of these goals in the paragraphs that follow. We also provide examples of ways in which ACCESS member societies fulfill these goals.

\section{Cost}

By definition, travel awards motivate awardees in part by financially sponsoring (partially or completely) their meeting attendance. Attendance at scientific society meetings is often discretionary rather than mandatory, and high or prohibitive cost has been identified as one of the strongest deterrents of conference attendance (Mair et al., 2018). Although the costs associated with attending annual meetings vary by society and by training level, the total membership, abstract, and registration fees for ACCESS societies average $\sim \$ 700$ for regular members, $\sim \$ 500$ for postdoctoral/early-career trainees, $\sim \$ 235$ for graduate students, and $\sim \$ 115$ for undergraduate students, not including travel, meals, or accommodations. Federal support for individuals to attend scientific society meetings is often not available, except for trainees and faculty working on federally supported projects or fellowships. Lack of funding for this type of expense may be a particularly strong determinant of participation for attendees from non-research intensive or minority-serving institutions (MSIs). This gap in opportunity might disproportionally affect young URM scientists, as students from URM backgrounds are more likely to come from low-income families (Kuh et al., 2006; Cullinane and Leewater, 2009; National Academy of Sciences, National Academy of Engineering, and Institute of Medicine [NASEM], 2011). Consistent with this idea, ASCB travel awardee data from 2008 to 2013 indicate that at least $30 \%$ of each of these cohorts reported receiving at least $51 \%$ or more needs-based financial aid for their undergraduate education (see Supplemental Table S3).

Past URM ASCB MAC awardee comments highlight cost as one of motivational dimensions affecting meeting attendance. These comments also point to travel awards as important tools that can be used to drive URM scientist attendance to annual meetings. 
TABLE 2. ASCB MAC travel awardee annual meeting objectives ${ }^{a}$

\begin{tabular}{|c|c|c|c|c|c|c|c|c|}
\hline \multirow{2}{*}{$\begin{array}{l}\text { Objective } \\
\text { Year }\end{array}$} & \multicolumn{8}{|c|}{ Percentage of respondents selecting objective } \\
\hline & $\begin{array}{c}2007 \\
(n=57)\end{array}$ & $\begin{array}{c}2008 \\
(n=55)\end{array}$ & $\begin{array}{c}2009 \\
(n=61)\end{array}$ & $\begin{array}{c}2010 \\
(n=97)\end{array}$ & $\begin{array}{c}2011 \\
(n=79)\end{array}$ & $\begin{array}{c}2012 \\
(n=97)\end{array}$ & $\begin{array}{c}2013 \\
(n=75)\end{array}$ & $\begin{array}{c}2016 \\
(n=56)\end{array}$ \\
\hline Learn about recent scientific developments & $70 \%(40)$ & $80 \%(44)$ & $81 \%(50)$ & $76 \%(74)$ & $67 \%(53)$ & $67 \%(65)$ & $60 \%(45)$ & $64 \%(36)$ \\
\hline Present my research at poster session & $63 \%(36)$ & $67 \%(37)$ & $74 \%(46)$ & $77 \%(75)$ & $72 \%(57)$ & $68 \%(66)$ & $73 \%(55)$ & $55 \%(31)$ \\
\hline Meet minority scientists & $53 \%(30)$ & $49 \%(27)$ & $55 \%(34)$ & $52 \%(50)$ & $32 \%(25)$ & $65 \%(32)$ & $33 \%(25)$ & $34 \%(19)$ \\
\hline Other & $7 \%(4)$ & $6 \%(3)$ & $7 \%(4)$ & $6 \%(6)$ & $1 \%(1)$ & $5 \%(5)$ & $4 \%(3)$ & $0 \%$ \\
\hline Gain advice on career development & ND & ND & ND & ND & ND & ND & ND & $45 \%(25)$ \\
\hline
\end{tabular}

aThe percentages and numbers (in parentheses) of respondents identifying with each of the presented objectives are presented. ASCB MAC travel awardees were queried on their objectives for attending the ASCB annual meeting. Respondents were provided with a range of choices and instructed to select up to three, although some awardees selected more than three choices. When choosing "other," awardees were allowed to indicate their goals in attending the annual meeting using text. A predominant additional objective for annual meeting attendance included faculty accompanying or bringing students from their home institutions to the annual meeting. Due to participants being given the choice to select more than one objective, the percentages in this table do not total $100 \%$. Number of respondents $n$ varies as some participants did not answer all the questions in the survey ( $n=$ number of respondents; ND, not determined). Due to a gap in funding, the ASCB travel award program for underrepresented scientists was not evaluated in 2014 and 2015. For this reason, data for these years are not available and could not be included.

"I was awarded with a travel grant and without this award I could not have attended the ASCB meeting."

"Funding, the travel award helped me A LOT. I went to the conference because of the travel award because I didn't have enough money to travel or book a room or even a ticket."

"The programmatic activities offered by the MAC are essential for faculty at resource-constrained institutions. More should be done to offer support, not just to junior faculty, but also to mid-career individuals."

\section{Networking Opportunities}

Networking opportunities are motivational determinants that are often built into scientific society conferences. In fact, most ACCESS societies have sessions at their annual meetings that facilitate networking interactions among members. These can include structured and unstructured networking events. Some of these events are open to travel awardees specifically, while others are open to all members. Examples include receptions and peer or near-peer networking sessions organized around shared career or scientific interests and poster sessions attended by URM and WR members alike. Some societies hold orientation sessions for or assign meeting mentors to support meeting attendees, especially those who are new to the society.

The past URM ASCB MAC awardee comments listed here highlight how important networking opportunities can be for these scientists.

"This past year I was able to attend and present at the 2017 ASCB-EMBO conference using the MAC Travel Award. I enjoyed the special sessions specifically for MAC awardees, due to the fact that this allowed me to network with scientists at various stages in their careers, as well as interact with faculty that work on topics relevant to my project. An additional benefit is the opportunity to receive advice on potential approaches and methods relevant to my work from more experienced professionals."

TABLE 3. Extent to which ASCB MAC travel awardee annual meeting objectives were met from 2016 to $2018^{\text {a }}$

\begin{tabular}{|c|c|c|c|c|c|c|}
\hline \multirow{4}{*}{$\begin{array}{l}\text { Objective } \\
\text { Rating scale: } \\
\begin{array}{l}4=\text { great extent, } \\
3=\text { moderate extent, } \\
2=\text { slightly, and } \\
1=\text { not at all }\end{array}\end{array}$} & \multicolumn{6}{|c|}{ Achieved to "great" or "moderate" extent } \\
\hline & \multicolumn{6}{|c|}{ Year } \\
\hline & \multicolumn{2}{|c|}{2016} & \multicolumn{2}{|c|}{2017} & \multicolumn{2}{|c|}{2018} \\
\hline & $\begin{array}{c}\text { Percentage } \\
(n)\end{array}$ & Mean & $\begin{array}{c}\text { Percentage } \\
(n)\end{array}$ & Mean & $\begin{array}{c}\text { Percentage } \\
(n)\end{array}$ & Mean \\
\hline Network with scientists & $98 \%(49)$ & 3.6 & $84 \%(46)$ & 3.3 & $92 \%(50)$ & 3.4 \\
\hline Learn about recent scientific developments & $82 \%(40)$ & 3.3 & $98 \%(56)$ & 3.7 & $94 \%(48)$ & 3.7 \\
\hline Present my research at poster session & $98 \%(43)$ & 3.6 & $98 \%(55)$ & 3.9 & $97 \%(59)$ & 3.9 \\
\hline Gain advice on career development & $89 \%(34)$ & 3.3 & $80 \%(35)$ & 3.3 & $89 \%(40)$ & 3.9 \\
\hline Meet minority scientists & $88 \%(36)$ & 3.5 & $80 \%(37)$ & 3.2 & $82 \%(32)$ & 3.3 \\
\hline Experience a large scientific convention & $100 \%(35)$ & 4.0 & $100 \%(42)$ & 3.9 & $100 \%(42)$ & 3.9 \\
\hline Meet other minority students & $86 \%(30)$ & 3.3 & $80 \%(33)$ & 3.2 & $86 \%(33)$ & 3.1 \\
\hline
\end{tabular}

aFrom 2016 to 2018, respondents were asked to indicate the extent to which their objectives for attending the ASCB annual meeting were met, the top objectives from Table 2 were used as choices. $n$ values may vary from objective to objective for the same year, some participants did not respond to every question ( $n=$ number of respondents). All mean ratings were $>3.0$ on a four-point scale for the years that this area was assessed, 2016-2018. The rating scale used was as follows: $4=$ great extent, $3=$ moderate extent, $2=$ slightly, and $1=$ not at all. 
"Networking with minority and non-minority scientists was quite fulfilling."

"MAC provided a great opportunity to network with minority post docs who are hard to find at my institution."

\section{Professional Development Opportunities}

At ACCESS members' annual meetings, professional development opportunities come in the form of training sessions or workshops, often in a panel discussion format, that tackle important topics and are open to all. For example, for ASPET, these topics include negotiation, conflict resolution, interviewing skills, work-life integration, and self-care. ACCESS member societies have increased the number of these offerings considerably over time in order to offer programming that impacts specific audiences or target groups. For example, Supplemental Table S4 provides an overview of the ASCB professional development session offerings at the annual meeting between 2005 and 2017, including average participant rating. These offerings increase from two sessions with no specific target audience in 2005 to nine sessions aimed at different academic stages in 2017.

These built-in career development sessions are complemented by the additional inherent value of travel awards as career-advancing credentials. Individuals who successfully obtain travel funds from their scientific societies can cite the award as an accomplishment in their scientific trajectories (Carroll et al., 2008; King, 2013; Jassar, 2015). Awardee home institutions and academic programs can also benefit and view these awards as shared successes (Carroll et al., 2008). A related benefit is that all ACCESS member societies feature poster competitions open to a combination of students, postdocs, and junior faculty as part of their annual meeting programming, in which the best poster presentations in each category are recognized. These mechanisms collectively help document the travel awardee's continued growth as a scholar.

Quotes from past URM ASCB MAC travel awardees highlight the power of professional development sessions at our annual meetings and speak to the career-advancing potential of travel awards.

"I received an ASCB MAC travel award as a postdoc and then won the ASCB MAC poster presenter award. Additionally, the EE Just lectures have been amazing. I additionally attended a junior faculty senior postdoc training event, and I felt like that helped me when I first started my position."

"I participated in the MAC travel award/poster session. I found this to be a rewarding opportunity to network with other minority scientists and also get critical feedback from leaders in the field of cell biology.'

“The MAC travel award, which I received as a master's student, provided my first opportunity to travel to a national conference. I was able to strengthen my presentation skills and meet with several potential collaborators across the country. After having this opportunity, my applications for several other opportunities were strengthened, including my successful admission to a doctoral program and the obtaining of fellowships/scholarships."

\section{Decreasing Sense of Social Isolation for URM Scientists}

URM individuals can experience a sense of isolation that negatively impacts their career trajectories (Walton and Cohen, 2011; Moreira et al., 2019). As a result, URM-oriented professional conference programming in STEM research is designed to help develop their science self-efficacy, research confidence, and sense of belonging in science (Casad et al., 2016). Some of the annual meeting programming by ACCESS member societies includes opportunities for URMs to participate in professional development sessions specifically tailored to their needs and experiences. While these sessions are often open to all members (both URM and WR), they allow URM travel awardees to meet and interact with successful and well-established URM society members (see Supplemental Table S4). These sessions also allow WR scientists to be allies and supporters of their URM colleagues. Examples of these opportunities include award talks geared toward outstanding URM scientists and additional poster sessions, awards, and networking receptions geared toward URM travel awardees.

An important issue not directly addressed by travel award programs is that most speakers at national scientific society meetings are not members of URM groups. Thus, even if these programs result in greater URM participation at meetings, there remains a tangible gap that may counteract the ability of attendees to perceive themselves as scientists. Development of this identity may be especially important for student attendees, as the academic success of URM (but not WR) graduate students has been shown to correlate with degree of professional identification as a scientist (Kim-Prieto et al., 2013).

These quotes from past URM ASCB MAC travel awardees highlight the sense of belonging that travel awardees can experience through their attendance at our annual meetings.

\footnotetext{
"I am more determined than ever to finish my doctorate and become a scientist."
}

"It was empowering to see so many minorities excelling."

"The meeting reaffirmed my readiness to move into a $\mathrm{PhD}$ program. Before attending the conference, I was somewhat hesitant to start conversations with other researchers, but not I feel more comfortable interacting with more prominent researchers."

\section{PROGRAM IMPLEMENTATION}

In this section, we discuss how ACCESS member societies currently implement travel award programming at their annual meetings, highlighting elements that other societies without travel award programs or without specific travel award program elements might implement as part of successful programs.

\section{Finding Sponsors: How Scientific Societies Obtain Funding for Travel Awards}

Travel award programs can be funded through federal grants, such as IPERT and R25 grants. For example, the ASCB MAC has a long history of this type of funding (Segarra et al., 2017, 2019). Travel awards funded through federal grants are often associated with specific strategic programming or interventions at the relevant conferences and are usually not available solely for individuals attending single events like an annual meeting. 
In addition, not only do federal funds come with certain restrictions (e.g., awardees have to be U.S. citizens/permanent residents), but as diversity and inclusivity make their way to the forefront of scientific societies' missions, societies such as ASBMB, ASPET, and BPS have shown their commitment to these priorities by using their own revenue funds or member donations to, at least in part, run travel award programs for URM scientists at their annual conferences. Alternative travel award sponsors also include nonprofit organizations and foundations such as the National Geographic Society, the Rockefeller Foundation, the Bill and Melinda Gates Foundation, the Howard Hughes Medical Institute (HHMI), and the Burroughs Wellcome Fund (Le Duc and DeAcetis, 2011; Segarra et al., 2017). Among ACCESS member societies, travel awards for URM scientists vary from $\sim \$ 300$ to upward of $\sim \$ 1700$, with an average award of $\sim \$ 675$ among all of the various types of travel award categories.

\section{Applicant Recruitment}

ACCESS members disseminate their URM travel award programs using a combination of methods, including emails to their general membership, emails to their diversity-focused committees, announcements on their websites, and social media. Supplemental Table S5 describes the methods through which ASCB MAC travel awardees came to learn about the program opportunity between the years 2006 and 2016. ASCB MAC travel award respondents learned about the program primarily from the ASCB website/communications, such as emails, and from their mentors or professors.

This is synergistic with data from ASBMB showing an increase of almost 200\% in applications from 2019 to 2020 after the implementation of an email newsletter advertisement strategy for their URM travel award programs (see Supplemental Table S6). As part of this strategy, leading up the ASBMB annual conference and travel award deadline, newsletter emails advertising the URM travel award program were sent monthly to society membership at large using RealMagnet by Higher Logic software, a service that is accessible to associations and corporations for a fee and allows for cloud-based marketing that integrates email, social media, and mobile components.

In the experience of BPS, another strategy that has facilitated applicant recruitment is to have one centralized system for all travel award applications (URM and WR), streamlining the process and decreasing duplicate applications. Using this model, all travel applicants use the same application portal and disclose their eligibility for the different BPS travel award programs during the application process. All applicants disclosing a URM background are then considered for the appropriate travel award program(s). Using this system, the BPS URM travel award applicant number nearly doubled without affecting success rate (see Supplemental Table S7).

\section{Application Process}

ACCESS member societies use online systems like WebFormZ to streamline the review of applications and communication with members. Information collected through these applications often includes personal/demographic information, short writeups on applicants' professional aspirations and reasons for wanting to attend the conference, and a statement confirming their financial need for the travel award.
Eligibility for these travel awards is targeted to URMs who are students or faculty members at academic institutions, including undergraduate and graduate students, postdocs, and junior faculty, and/or other faculty at MSIs (Table 1). To qualify for one of these awards, applicants have to self-identify as belonging to one of these groups. No official verification of URM status is enforced; instead, an honor system is implemented in which applicants being selected for an award have to declare that they belong to one of these target groups during the application process (and then again when the award is accepted). While some societies limit the number of times an individual can be granted a travel award, others do not. In general, society membership and abstract submission are part of the eligibility requirements for application. In the experience of ACCESS member societies, membership and abstract requirements have not hindered the submission of applications to their respective travel award programs.

There is a high degree of agreement among ACCESS members regarding the materials they require to apply for travel awards (Table 1). These include a curriculum vitae, a research summary (e.g., meeting abstract), and usually a letter of support. For trainees in early stages of their careers, the application process is an opportunity to polish their grant-writing skills, learn to request/obtain important application documents such as letters of recommendation, write a research summary, and articulate their future career goals. Awardees (and to a certain extent, their mentors) may benefit from the travel award application process, especially if it is a shared experience, a joint mentoring opportunity, and a common marker for success. In fact, some URM faculty travel awardees indicate that one of their objectives in annual meeting attendance is to accompany and mentor their students (Table 2).

\section{Review of Applications}

The use of online systems to review applications facilitates file management, enables reviewers to automatically recuse themselves in cases of potential conflicts of interest, and allows a single pool of travel award applications to easily be broken down according to career level (Table 1). ACCESS member societies differ in the way that they assign reviewers to assess applications; while some, such as BPS and ASPET, build groups of judges from multiple committees within the society, others such as the ASCB MAC run travel awards through their diversity and inclusion committees. Membership in these society committees can vary from year to year and is open to all society members (not limited to URM scientists). In general, ACCESS member societies provide their travel award application reviewers a rubric to facilitate their evaluation of candidates, although these rubrics can vary in the weight they assign to each field. ASPET applicant selection is primarily abstract based, while ASBMB's rubric allows for the inclusion of specific merits that can be used for selection of awardees. ACCESS member societies agree that rubrics are helpful, but it is important to note that reviewers often make decisions on the specific circumstances of each candidate to ultimately select awardees who will benefit the most from the award. Importantly, ACCESS member societies agree that, while science can be used as one of the determinants for travel awardee selection, it can be problematic to use it as the only determinant for application review. Sometimes URM scientists, especially young trainees, may not have access to the 
mentoring or resources needed to craft superb applications. A more compelling way to assess the potential benefits of a travel award application is therefore to identify the reasons for an applicant wanting to attend the meeting and why it is important for the candidate to receive the award. In general, what societies look for in awarding travel grants to their annual conferences is a combination of evidence of a candidate's scientific achievement and a strong interest in attending/benefiting from the event.

To amplify impact and maximize diversification/inclusion of annual meeting attendees, ACCESS member societies like ASBMB engage with URM travel award applicants who were not selected as travel awardees in the review process to ensure that they know they are welcome at the meeting. It is the case that many of the URM scientists who are not selected for travel awards ultimately attend the meeting and can benefit from networking and career development opportunities at the conference. Moreover, in 2020, ASBMB URM travel award applicants who were declined were ultimately added to the regular pool of applicants for graduate/ postdoctoral travel awards, maximizing the opportunities for meeting attendees from URM backgrounds.

\section{Award Notification and Requirements}

The notification of award is usually sent to awardees using an email letter that also contains relevant information like the amount of the award and reimbursement guidelines, as well as deadlines for confirmation of acceptance, meeting registration, and housing reservations. ACCESS member societies such as ASCB aim to notify awardees with enough time in advance for them to be able to register and make travel arrangements for the conference and benefit from early bird prices, often about 10 weeks before the meeting and two weeks after the application deadline. While some of the ACCESS member societies, like BPS, have no session attendance requirements associated with accepting a travel award, others such as ASPET, ASCB, and ASBMB do. If it is the case that awardees are expected to attend specific sessions at the conference, these requirements are specified in the letter of award. In general, societies request that awardees officially accept the award by completing, signing, and returning a contract form. On this form, a small amount of information is collected from awardees, including demographic information like confirmation of U.S. citizenship and URM status. While this information is also required or disclosed on the original application, as part of the honor system used to verify citizenship and URM status of awardees, the applicants accepting a travel award have to confirm belonging to one of these target groups when accepting the award. Collection of this information is particularly important for travel award programs that are federally funded, as it allows the awarded scientific society to comply with reporting requirements from the federal funding agency. Some of the ACCESS member societies, like ASBMB, collect additional information at this stage related to career and research goals to help inform matching of travel awardees to annual meeting mentors.

In terms of the amount of the award, it is important to keep in mind that, while the awarded amount might not cover all of the awardee's travel expenses, many students are able to use a society's partial award to leverage additional funding from their home institutions or other entities. However, this does not seem to be a widespread trend.

\section{Reimbursement Method}

ACCESS member societies generally reimburse travel expenses using one of two methods: 1) reimbursement after submission of expense report once the meeting has concluded, or 2) in the form of a check for the awarded amount to be picked up at the meeting. There are currently discussions on how to best accommodate the financial constraints of young scientists through adjustments to the way reimbursements are given to awardees (Sagers, 2019). Out of the two methods described, providing a check for the awarded amount is considered the better and less disruptive alternative (Sagers, 2019). Radically different alternatives such as fund advances are considered unlikely to replace the current practices due to financial (tax) and accounting oversight constraints from the societies' perspective, especially given the volume of awards for some of the societies. At the same time, it is recognized that both mechanisms require awardees to pay many expenses before reimbursement is received, which represents a financial strain, especially for URM students, who may come from low-income families (Kuh et al., 2006; Cullinane and Leewater, 2009; NASEM, 2011). For example, ASCB travel awardee data from 2008 to 2013 indicate that most of the participants reported receiving needs-based financial aid for their undergraduate education (see Supplemental Table S3).

\section{ASSESSMENT}

Assessment of these programs usually takes place in the form of anonymous online surveys administered to travel awardees after the event. Awardees complete these on their own time (not on-site) to provide feedback on the utility and effectiveness of professional development sessions and networking opportunities attended while at the annual meeting. These surveys also collect demographic information such as race and ethnicity as well as gender identity. Most ACCESS member societies assess travel award programs indirectly, in that the survey questions are not award related but rather programming related. In the example of some societies such as ASCB and ASPET, the events assessed by travel awardees are the professional development sessions for which their attendance was required. For other societies, like ASBMB and BPS, the surveys administered to travel awardees are no different from the ones administered to general membership at the end of the conference. In some cases, travel awardees may receive one survey from the society requesting feedback on the meeting itself and a second from the travel award administrators assessing specific program offerings associated with the award. Survey questions may be aimed at obtaining feedback from members regarding needed or future programming of interest. An aggregate report is usually generated at the end of one program cycle to share with society leadership members responsible for administering and implementing the travel award program. This report helps to secure additional resources from the society for future iterations of the program and informs future programming and grant writing. For example, ASCB has used these comments to shape the content of professional development session offerings at the annual meeting (see Supplemental Table S4).

\section{Assessing Travel Award Impact on Overall Society Membership}

Although ACCESS member societies aim to increase the proportion of URM scientists in their membership through travel 
awards (society membership is required for travel award eligibility as mentioned earlier), assessing long-term travel award impact on society membership demographics has proven challenging. For example, ACCESS societies request ethnicity and race information during the membership onboarding process; however, the questions are optional, and a fraction of members choose not to disclose belonging to URM groups. For example, $46 \%$ of ASPET members and 19\% of ASCB members at the end of 2019 declined to answer or provided no answer to questions related to ethnic/race background. Moreover, our data indicate that a small percentage of URM travel awardees remain members of the societies that provided them with the award. For example, if we retrospectively assess whether past ASBMB URM travel awardees remain ASBMB members, $80 \%$ of $2015-2018$ travel awardees are not currently ASBMB members. This suggests that URM member retention is an important outcome that needs to be assessed to continue to advance an inclusive climate within our scientific societies.

\section{COLLECTIVE CHALLENGES AND RECOMMENDATIONS}

In the following sections, we discuss some of the challenging elements in the implementation of travel award programs as well as a set of recommendations for future improvements based on ACCESS member societies' current practices.

\section{Maximizing Travel Award Impact by Addressing Most Motivational Dimensions}

While this article has predominantly focused on the standalone format that is characteristic of most travel awards, ACCESS members strongly encourage other societies to expand the benefits of conference attendance to URM travel awardees beyond monetary incentives alone. Incorporating other motivational dimensions has enabled scientific societies not only to ensure diversity at annual meetings, but also to sustainably promote inclusivity and increase the value of membership to URM scientists. This optimization can be achieved by hosting networking events to integrate URM scientists into the larger fabric of the society as well as professional development sessions to better prepare URM awardees for challenges that they might face at their next career transition. Thus, additional travel award programming should add onto and complement rather than replace other recognized benefits of annual meeting attendance.

\section{Assessing the Defined Goals and Outcomes of Travel Awards}

Comparison of methods used by ACCESS member societies to assess travel award programs has revealed that few societies specifically evaluate the effectiveness of travel awards to increase URM scientist representation at annual meetings, provide networking and professional development opportunities to URM scientists, or create a community of URM scientists at annual meetings. While current models of assessment instead focus on the efficacy of specific sessions during the annual meeting, ACCESS recommends collectively moving toward a model that also measures the extent to which the key URM travel award program goals and outcomes are being met. Such evaluation will be needed to develop more effective interventions, and should be shared widely with other societies and the academic community.
If a society does not have a set of established goals for their travel awards, then, it is important to engage in conversations with the leadership of the society regarding the goals and the scope of their travel award program, especially because resources and personnel will be needed to develop a successful, assessable program. We invite societies to use the four goals articulated at the beginning of this Essay as a starting point to formulate their own set of desired outcomes, which will serve as a basis for assessments of effectiveness. It may be useful to conduct an initial assessment to determine what resources might be needed in the future (time, effort, funding) to meet WR and URM membership needs. Enhancing diversity at annual meetings may increase satisfaction of both URM and WR attendees and would be an important outcome to assess. Having these data can potentially empower societies to adopt evidence-focused approaches to their travel award programming, allowing new opportunities for collaboration and partnerships with other societies and funding agencies or entities.

Travel award outcomes are easily measurable over a shortterm scale. Awardees can be asked about the number of scientists they met at different career levels, as well as about their sense of whether they were good contacts or were welcoming. Such feedback can help us measure how inclusive an environment our membership is providing, similar to a climate survey. The answers to these questions might inform a society's decision to put additional programs in place to facilitate these interactions, if needed.

Assessing the short-term efficacy of travel award programs raises the question of whether or not we should also collect preassessment information from awardees before they engage with the program, perhaps as part of the application process. The awardees' expectations from participation in the conference can be incorporated into the society's goals and objectives for the travel award program as well as the outcomes evaluated after the experience. For this reason, we recommend that survey questions assess the mission of the travel award program as directly as possible, including the degree to which URM scientists were able to meet their expectations, network, develop professionally and feel like part of a community.

\section{Amplifying Impact after the Meeting and/or at the Awardees' Home Institutions}

There may be additional ways to encourage and prepare awardees to apply the information learned by attending the annual meetings to amplify impact at their home institutions. For example, societies can provide tools awardees can use to present what they learned at the conference at their home campuses, broadening and amplifying the benefits of content learned. A potential initiative to consider is contacting the mentors of the awardees (letter) to thank them for their support of a URM scientist-in-training. This can be done on behalf of URM scientists ranging from undergrads to even junior faculty members (letters to their chairs). Societies are thinking creatively about how to extend the impact of our annual meetings beyond the time/space of the meetings themselves, perhaps by supporting local chapters, for example, the student chapters initiated by ASBMB. ASBMB also supports URM travel awardees after their annual meeting by providing sustained access to a society mentor who engages the mentee through virtual meetings 
throughout the year in a program based on the career coaching model described by Williams et al. (2017). These mentors are members of the ASBMB diversity-focused committee and serve as supplemental advisors for these trainees offering students long term career advice/scientific development support.

\section{Supporting Trainees during Transition Periods}

Successful progress through transition periods along the academic career path can be critical points for URM retention and persistence in STEM fields (Allen-Ramdial and Campbell, 2014; Segarra et al., 2019). Individuals undergoing academic transitions would benefit from opportunities to stay connected with their societies even as they temporarily lose affiliation with a home academic institution. Societies are perfectly positioned to fill this need by designating some travel awards for scientists in transition who would benefit from attending annual meetings but have no current academic affiliation or institutional support.

\section{CONCLUSIONS}

Given the current challenges we collectively face in supporting diversity and inclusion in STEM fields, we believe that travel awards can provide the initial networking contacts necessary to promote URM in scientific fields and support a sense of identity in a specific discipline. We have put forward a set of recommendations for scientific societies to consider as they implement or design travel award programs. These recommendations are intended to help societies position themselves to iteratively increase the effectiveness of their travel award programming for the benefit of their URM members using assessment data.

Now more than ever, disciplinary scientific societies can find evidence-based solutions to support STEM students and trainees to persist in STEM fields and use the society community throughout their careers despite changing academic or professional affiliations. This becomes even more important for individuals who may not be part of a group or program of study at their home institutions, for whom the society might fulfill the role of a home community.

As an effective strategy to achieve collective impact, Kania and Kramer outline the conditions that need to be met through cross-organization collaborations, including a common agenda and shared measurement strategies (Kania and Kramer, 2011, 2013). By establishing the ACCESS meta-organization, the member societies have adopted a common agenda and thus established the foundation for collaborative efforts to bring about collective change. As we look to the future and the potential benefits of more robust assessment strategies for travel award programs at our societies, we will examine the possibility of adopting shared assessment metrics. We have also articulated interesting long-term (longitudinal) research questions that surfaced, including: What are the best professional development opportunities to "attach" to travel award programs, especially given the limited amount of time during annual meetings? Are societies more likely to retain members who receive a travel award? Are society members who receive a travel award more likely to give back and become involved in society leadership? Are awardees who have a bad experience less likely to return to another society conference? How can we effectively assess URM member retention as a function of society climate?
Through the exchange of information facilitated by meta-organizations like ACCESS, we are better positioned to begin addressing some of these questions and learning from each other.

\section{ACKNOWLEDGMENTS}

We thank the past and current members of ACCESS. We also thank Joy Quill (www.quillassociates.com), Deborah McCall, Fabiola Chacon, Desiree Salazar, Sydella Blatch, Jim Vigoreaux, and Erika Shugart for their key roles in the implementation of ASCB programs for which data are presented and discussed in this publication (supported by the National Institutes of Health grants T36-GM008622 and R25GM116707). We are thankful to Amanda Schut from Kate Winter Evaluation for assistance in identifying relevant social science literature relevant to our study. ACCESS work is supported by the NSF, grant number 1744098 to M.R.-A. and V.A.S. The use of data from past aggregate assessment reports in this Essay was approved by the Institutional Review Board at High Point University, approval no. 201910-858. The first in-person convening of ACCESS was supported by the HHMI.

\section{REFERENCES}

Ahern-Dodson, J., Clark, C. R., Mourad, T., \& Reynolds, J. A. (2020). Beyond the numbers: Understanding how a diversity mentoring program welcomes students into a scientific community. Ecosphere, 11(2), e03025.

Allen-Ramdial, S. A. A., \& Campbell, A. G. (2014). Reimagining the pipeline: Advancing STEM diversity, persistence, and success. BioScience, 64(7), 612-618.

Bolaños-Guzmán, C. A., \& Zarate, C. A., Jr. (2016). Underrepresented minorities in science: ACNP strives to increase minority representation and inclusion. Neuropsychopharmacology, 41(10), 2421.

Cameron, L. C. (2013). International Institute for Collaborative Cell Biology and Biochemistry-history and memoirs from an international network for biological sciences. CBE-Life Sciences Education, 12(3), 339-344.

Campbell, A. G., Leibowitz, M. J., Murray, S. A., Burgess, D., Denetclaw, W. F., Carrero-Martinez, F. A., \& Asai, D. J. (2013). Partnered research experiences for junior faculty at minority-serving institutions enhance professional success. CBE-Life Sciences Education, 12(3), 394-402.

Carroll, M. A., Skeete, D., \& Catapane, E. J. (2008). Its time to step into science at Medgar Evers College. In Vivo, 30(1), 22.

Casad, B. J., Chang, A. L., \& Pribbenow, C. M. (2016). The benefits of attending the Annual Biomedical Research Conference for Minority Students (ABRCMS): The role of research confidence. CBE-Life Sciences Education, 15(3), ar46.

Cullinane, J., \& Leewater, L. H. (2009). Diversifying the STEM pipeline: The Model Replication Institutions Program, Washington, DC: Institute for Higher Education Policy. Retrieved January 8, 2016, from www.ihep.org/ sites/default/files/uploads/docs/pubs/report_diversifying_the_stem _pipeline_report.pdf

Edwards, A. (2004). MAC-E. E. Just Lectureship 2004: Biographical sketch, Sandra Murray, 2004. Retrieved January 15, 2020, from www.ascb.org/ society-news/mac-e-e-just-lectureship-2004

Ford, H. L., Brick, C., Azmitia, M., Blaufuss, K., \& Dekens, P. (2019). Women from some under-represented minorities are given too few talks at world's largest Earth-science conference. Nature 576(7785), 32-35.

Jassar, A. S. (2015). Experience from the inaugural TSRA traveling fellowship award. Annals of Thoracic Surgery, 100(6), 2411.

Kania, J., \& Kramer, M. (2011). Collective impact. Stanford Social Innovation Review, 9(1), 36-41.

Kania, J., \& Kramer, M. (2013). Embracing emergence: How collective impact addresses complexity. Stanford Social Innovation Review, 11(2), 1-7.

Kim-Prieto, C., Copeland, H. L., Hopson, R., Simmons, T., \& Leibowitz, M. J. (2013). The role of professional identity in graduate school success for 
under-represented minority students. Biochemistry and Molecular Biology Education, 41(2), 70-75.

King, L. (2013). Helping early career research scientists ascend the professional ladder. Trends in Biochemical Sciences, 38(8), 373-375.

Kuh, G. D., Kinzie, J., Buckley, J. A., Bridges, B. K., \& Hayek, J. C. (2006). What matters to student success: A review of the literature. Washington, DC National Postsecondary Education Cooperative, National Center for Education Statistics

Le Duc, J. W., \& DeAcetis, J. (2011). Review and assessment of the American Society of Tropical Medicine and Hygiene travel awards program, 19912010. American Journal of Tropical Medicine and Hygiene, 85(3), 409-413.

Mair, J., Lockstone-Binney, L., \& Whitelaw, P. A. (2018). The motives and barriers of association conference attendance: Evidence from an Australasian tourism and hospitality academic conference. Journal of Hospitality and Tourism Management, 34, 58-65.

Mair, J., \& Thompson, K. (2009). The UK association conference attendance decision-making process. Tourism Management, 30(3), 400-409.

Moreira, R. G., Butler-Purry, K., Carter-Sowell, A., Walton, S., Juranek, I. V., Challoo, L., ... \& Spaulding, A. (2019). Innovative professional development and community building activity program improves STEM URM graduate student experiences. International Journal of STEM Education, 6(1), 34.

Mourad, T. M., McNulty, A. F., Liwosz, D., Tice, K., Abbott, F., Williams, G. C., \& Reynolds, J. A. (2018). The role of a professional society in broadening participation in science: A national model for increasing persistence. BioScience, 68(9), 715-721.

National Academy of Sciences, National Academy of Engineering, and Institute of Medicine. (2011). Expanding underrepresented minority participation: America's science and technology talent at the crossroads. Washington, DC: National Academies Press.
National Institutes of Health. (n.d.). Populations underrepresented in the extramural workforce. Retrieved January 10, 2020, from https://diversity .nih.gov/about-us/population-underrepresented

Potvin, D. A., Burdfield-Steel, E., Potvin, J. M., \& Heap, S. M. (2018). Diversity begets diversity: A global perspective on gender equality in scientific society leadership. PLOS ONE, 13(5), e0197280.

Ramirez, J. J., \& Tonidandel, S. (2009). SOMAS-URM: The evolution of a mentoring and summer research program. Journal of Undergraduate Neuroscience Education, 8(1), A69.

Sagers, J. (2019, February 14). Reimbursement policies make academia less inclusive. Science Careers. doi: 10.1126/science.caredit.aax0053

Segarra, V. A., Blatch, S., Boyce, M., Carrero-Martinez, F., Aguilera, R. J., Leibowitz, M. J., ... \& Edwards, A. (2019). Scientific societies advancing STEM workforce diversity: Lessons and outcomes from the Minorities Affairs Committee of the American Society for Cell Biology. Journal of Microbiology and Biology Education 21(1). doi:10.1128/jmbe.v21i1.1941

Segarra, V. A., Carrero-Martínez, F., \& Shugart, E. (2017). The Minorities Affairs Committee of the American Society for Cell BiologyFostering the professional development of scientists from underrep resented minority backgrounds. CBE-Life Sciences Education, 16(2), le1.

Steiner, J., \& Leinwander, P. (2017). Using the Health Physics Student Volunteer Program for a research project sponsored by the Medical Section of the Health Physics Society. Health Physics, 112(4), 352-356.

Walton, G. M., \& Cohen, G. L. (2011). A brief social-belonging intervention improves academic and health outcomes of minority students. Science, 331(6023), 1447-1451.

Williams, S. N., Thakore, B. K., \& McGee, R. (2017). Providing social support for underrepresented racial and ethnic minority PhD students in the biomedical sciences: A career coaching model. CBE-Life Sciences Education, 16(4), ar64 